\title{
Does External Debts Promote Sustainable Economic Development in Developing Countries?
}

\author{
James Daniel Chindengwike \\ ,Department of Finance, Accounting and Economics, Faculty of Commerce and Business Studies, St. John's University of \\ Tanzania - Dodoma, Tanzania
}

\begin{abstract}
External debts is one of the major sources of revenue to developing nations that normally do not have an enough industrial support and is illustrated by a small human development index. The aim of this paper is to test whether external debts promote sustainable economic development in developing countries or not. The study opted a time series data research design where by secondary data were used. This study used economic data from 1999-2020 financial years (Quarterly data). The study involved 80 observations. Kenya was purposively sampled to be used as research area of this study. The data collected from different reliable sources which included the International Financial Statistics (IFS), World Bank's Statistical Database, The Treasury of Kenya, Ministry of Devolution and Planning and the Kenya National Bureau of Statistics. The results of the study revealed that there is long term associations between external debts and sustainable economic development with P- Value of 0.0001 . Another finding revealed that there is statistical significantly in all other macroeconomic variables in the predictable direction with $P$ - Value of 0.0011, except broad inflation and money that have vague signs. In short-run revealed that external debts affect statistically significance economic development with a negative direction $\mathbf{P}$ Value of 0.0064 . The study recommends that the government should think about adopting other sources of finance articulate via taxation and reduce borrowing outside to minimize assistance from developed nations. The government should also assign extra resources to savings in human capital education as efficiently labor has the effect of promoting sustainable economic development crosswise all models in the short run. Particularly population expansion rate should be proscribed through increasing utilize of social services such as family planning or sensitization to reduce support pressure on imperfect resources which deject economic development.
\end{abstract}

Keyword: Developing Countries, External Debts, Kenya, Sustainable Economic Development

\section{INTRODUCTION}

$\mathrm{E}$ xternal debts are one of the majority imperative policy gears that rich nations use for serving poor nations to change population wellbeing and help institutional and economic growth [3]. The idea of external debts is broadly used and established as a stream of financial resources from developed nations to developing nations on growth grounds. External debts are funds that one nation willingly transfer to another, which can take the form of loan. According to [10] debts include money transferred across borders by government organizations and international organization. Previous studies show that external debts are hypothetically believed to improve economic development [15]. Nevertheless, [1] argued that the impact of external debts on economic development which is the boost eventually of a country's real output of goods and services are vague. Empirical evidence revealed that, economic development as ongoing and stable alter in the long run which comes about by a continuing raise in the rate of investments and population [2]. Empirical evidence observed that the economic development as an extension of the system in one or more magnitudes with no a change in its composition [5]. So economic development is connected to the sustained and quantitative increase in the nations per capita production or income attended by increase in its labor power, utilization level, capital and quantity of trade. Economic development is a raise in the capability of an economy to create goods and services, evaluated from one period of time to another. Nevertheless, the position and impact of external debts in the economic development of developing countries have been and are divisive issues to researchers and economists. This is because the usefulness of external debts has become the theme of wide examination, because of the recent growing realization that a large number of developing countries have had only limited success even with the increased influx of aid they receive [12].

According to [8] in 1930s and 1940s harassed those external debts can raise physical capital accumulation as results economic development they concluded that, external debts plug in the economy gap in developing nations. Their theory is reversed by Chenery and Strout, in the Two gaps where they recommended that, apart from economy gap, there are foreign exchange gap that deter the developing nations to importation of the capital goods. Thus, they argue that, external debts give money to the developing nations for the importations of capital goods. Developing nations are typified by reserve starving economies, particularly capital connected. Capital to increase economic development and welfare is basically insufficient nationally, which as a result warrants the need for outside capital. The only outside capital willingly obtainable to hold up growth activities have to come from external debt. It started in the late 1940's with the reason of recreation the war-torn economy of Western Europe [7]. Three African economies have conventional large inflow of external debts after 1950s. Kenya mortal a developing country respects its revenue through via exports of primary 
products. In effort to attach to obtainable household resources, succeeding governments have acquired enormous sums of outside loan to finance national development plans. High levels of foreign debts in Kenya pretense large challenges on the economy because big part of exports is committed in servicing these debts instead of being put into domestic savings thus falling the projection of economic development [13].

There is important raise in foreign inflows, but the economic development attains by many developing countries has not been acceptable. For example, in 2012, the Sub Saharan Africa region conventional a share of over $25 \%$ of total world loans $[2,6]$. How greatly of this transform into economic development is the query? So, the real responsibility of external capital inflow has been an area of argument. Kenya has been one of the main beneficiaries of foreign debt most of it aimed at supporting economic development by aiming macro- economic permanence of the financial system, employment, social and economic infrastructure, , governance, foreign exchange, reforms and caring assistance among others with mutual loans accounting for $70 \%$ and external debt accounting for $72 \%$ of total joint loans [6]. Previous study shows that aid has negative impact on economic growth in Kenya [16] while the study by [4] found that aid has direct relationship between external debts and economic development in Kenya.

Previous study revealed that the main bilateral loans sources to Kenya include United States of America (USA), Kingdom (UK), Germany, Japan and Netherlands while main joint loans sources include the World Bank, European Commission (EC), and the African Development Bank (AFDB), the International Financial Statistics (IFS), although these interference, it is evident that even if prominent donor interference in the nation's economy, leisurely economic development and poverty remain intrinsic for many years. Despite this inconsistent situation, there is little researches capture the notice is to test if external debts promote sustainable economic development in developing countries [9].

\section{LITERATURE REVIEWS}

External debts are the one of the sources finance government spending in many developing countries. The addition of foreign debts should not indicate slow economic development. It is a nation's incapability to meet its debts agreement compounded by the require of in order on the personality, composition and scale of foreign debts [4]. Previous study suggested that nations borrow for two broad groups; macroeconomic reasons to either finance higher investment or higher consumption and to avoid hard budget problem [9]. This entails that an economy borrows to increase economic development and reduce poverty. Previous study done by [9] revealed that when debts reach an assured level, it becomes to have unfavourable impacts, debts servicing becomes a massive weight and nations find themselves on the incorrect side of the loan-lifer curve, with loan crowding out investment and development. The debts service load has militated against Kenya's rapid economic growth and exacerbate the social trouble. Empirical evidence shows that all components of debts have a negative impact on long - run economic development [12]. The Granger causality test indicated that the existence of a short- run causality connection between all debt's method and economic development in the short-run. Previous study revealed that the export earnings have a significance positive effect while external debts and inflation had indirect effect on Sudan's economic development [3]. Previous study done by [8] that loan service is negatively related to economic development in the long run. The causality test showed negative causality between loan service and economic development.

Empirical evidence revealed that the significant decrease in the stock of external debts proposed for extremely in loaned poor nations (HIPC) would straight increase per capita income growth by about $1 \%$ point per year [3]. Minimization in external debts service could also provide a negative effect to development through their impacts on public speculation. Empirical evidence revealed that there is positive relationship between foreign debts and economic development in Pakistan [6]. Previous study shows that external debts are negatively and significantly connected to economic development [7]. Empirical evidence observed that the increase in external debts will cause to decrease in economic development [2]. Empirical evidence reported that debts servicing burden has a negative impact on the output of labour and capital, thereby unfavourably moving economic development [2]. Previous study argued that debts payment to Nigerian creditors to affect the economic growth both positively and negatively [11]. But [13] found that Nigeria is in loaned to the different creditors which do not predict well for the nation. likewise, [7] in their study on the impact of external debts on economic development in South Africa and Nigeria using neoclassical growth model revealed that a negative effects of debts and its servicing needs on development in the two nations while external debts give positively to development up to a direct after which its donation becomes negative in Nigeria [8]. Previous studies found positive effects of external debts on economic growth in Nigeria [4,9]. For example; [4, 11] examined the impacts of external debts on the economic development in Nigeria from 1970 to 2010. The results revealed that there is short and long run relationship among the variables and completed those external debts have given positively to economic development in Nigerian. Also, the study also found positive effects on economic development [9]. Several developing countries depend on loans to support budget deficit through borrowing external debts. Some of efforts done by international Nations (UN) through sustainable Development Goals up to 2030 still the economic growth of economic development goes done for example from 2015/16, 2016/17, 2018/19 and 2019/2020 Kenya decrease economic growth by $0.2 \%, 0.4 \%$ and $0.7 \%$ respectively. 
Although the developing country borrow funds still the economic growth rate drop. So, there is gap that exists between external debts and sustainable economic development in developing country. Therefore, the researcher needs to fill the gap between external debts and sustainable economic development in developing country

\section{RESEARCH METHODOLOGY}

This study adopted quantitative research approach since employ the external debts and economic development in Kenya. The study opted a time series research design where by secondary data were used. This study used economic data from 1999-2020 financial years (Quarterly data). The study involved 80 observations. Kenya was purposively sampled to be used as research area of the study. The reason for preference Kenya as study area is due to the truth that the Kenya is one of the developing countries which depend on loans compared to other countries in developing countries. The data collected from different reliable sources which included the International Financial Statistics, World Bank's Statistical Database, The Treasury of Kenya, Ministry of Devolution and Planning and the Kenya National Bureau of Statistics.

Econometric Model Specification; Vector Error Correction Model was used to test if external debts promote sustainable economic development in developing countries. The reason of choosing the Vector Error Correction Model is due to the truth that the dependent variable of the research is "Continuous Data in Nature (\% GDP)" consequently; the Vector Error Correction Model is fitting for this study.

$Y=A_{t} F(K, L) \ldots \ldots(i)$

Whereby $=$ Real Output; $K=$ Capital, $L=$ Labor Input; $A_{t}$ =Measure of Technology which is Time Dependent (Total Factor Productivity or Solow Residual at time t.).

$G D P=(K, E L, D E B T S, E R, I N F, B M, P O P) \ldots \ldots$ (ii)

Whereby: $G D P=$ Gross Domestic Product; DEBTS = External Net Debts; $K=$ Gross Capital Formulation; $E L=$ Effective Labor; $E R=$ Official Exchange Rate; $I N F=$ Inflation; $B M=$ Broad Money and $P O P=$ Population Growth Rate.

$Y_{i t}=\beta_{0}+\beta A_{i t}+X_{i t}+\mu_{i t} \ldots \ldots \ldots \ldots \ldots \ldots$. (iii)

Whereby: $Y_{i t}=$ Economic Growth; $\beta_{0=}$ Constant Term; $\beta_{A i t}=$ Debts Variable, $X_{i t}=$ Contains all the controls included in the regression $\mu_{i t=}$ Error Term. Therefore, the fundamental models predictable in the study can be rewritten by the following linear forms.
$G D P_{t}=\beta_{0}+\beta_{1} K+\beta_{2} E L+\beta_{3} D E B T S+\beta_{4} E R+\beta_{5} I N F+\beta_{6} B M$ $+\beta_{7} P O P+U_{t}$

Whereby: $G D P t=$ Gross Domestic Product; $\beta_{0=}$ Constant Term; $K=$ Gross Capital Formulation; $E L=$ Effective Labor; $D E B T S=$ External Net Debts; $E R=$ Official Exchange Rate; $I N F=$ Inflation; $B M=$ Broad Money; $P O P=$ Population Growth Rate; $U_{t}=$ Error Term

\begin{tabular}{lccr}
$\ln G D P_{t}=\beta_{0}+\beta_{1} \ln K+$ & $\beta_{2} \ln E L+$ & \multicolumn{2}{c}{$\beta_{3} \ln D E B T S+$} \\
$\beta_{4} \ln E R+\beta_{5} \ln I N F+\beta_{6} \ln B M$ & + & $\beta_{7} \ln P O P+$ & $U_{t}$
\end{tabular}
(v)

Whereby: $G D P=$ Gross Domestic Product; $\beta_{0=}$ Constant Term; $K=$ Gross Capital Formulation; $E L=$ Effective Labor; $D E B T S=$ External Net Debts; $E R=$ Official Exchange Rate; $I N F=$ Inflation; $B M=$ Broad Money; $P O P=$ Population Growth Rate; $U_{t}=$ Error Term

Hypothesis of the Research: $\mathrm{H}_{0}$ : There is no direct relationship between external debts and sustainable economic growth in developing countries

\section{RESULTS AND DISCUSSION}

A. Unit Root Tests: For non-stationary time series to be made stationery, it has to be differenced d times. In this case, the time series is said to be integrated of order $d$. If a time series $Y t$ is stationary, it is said to be integrated of order zero, denoted by $Y t \sim I(0)$ but most economic time series are generally I (1). This implies that they become stationary after taking their first differences [5]. Augmented Dickey-Fuller (ADF) was conducted to test for existence of the Unit root test. The test requires the estimation of the following regression:

$m i$

$\Delta Y t=\beta 1+\beta 2 t+\delta Y t-1+\sum(\alpha i \Delta Y t-i)+\varepsilon t i=1$

Whereby: $\varepsilon t=$ A Pure White Noise Error Term

$\Delta Y t-1=(Y t-1-Y t-2), \Delta Y t-2=(Y t-2-Y t-3)$ etc., are Successive Lagged Differences Augmented; $\beta 1=$ Intercept, $\beta 2=$ Trend Coefficient, $\mathrm{t}=$ Time or Trend Variable and $m=$ The Number of Lag Terms Selected.

The hypotheses of this test will be: H0: $\delta=0$ (there is a unit root -the time series is non-stationary); $\mathrm{H} 1: \delta<0$ (there is no unit root - the time series is stationary). If the calculated absolute value of the $t$ statistic goes beyond the ADF critical values, we reject the hypothesis that $\delta=0$ implying that the time series is stationary and vice versa. 
Table 1: PP Test Results in Levels and First Difference

\begin{tabular}{|c|c|c|c|c|c|c|c|}
\hline \multicolumn{2}{|c|}{ Method } & Statistic & Prob.** & \multicolumn{2}{|l|}{ Method } & \multicolumn{2}{|c|}{$\begin{array}{l}\text { Statistic } \\
\text { Prob.*** }\end{array}$} \\
\hline \multicolumn{2}{|c|}{ PP - Fisher Chi-square } & 25.6491 & 0.2671 & \multicolumn{2}{|l|}{ PP - Fisher Chi-square } & $\begin{array}{c}292.0 \\
9\end{array}$ & 0.0000 \\
\hline \multicolumn{2}{|c|}{ PP - Choi Z-stat } & 1.47048 & 0.9293 & \multicolumn{2}{|l|}{ PP - Choi Z-stat } & $\begin{array}{c}- \\
15.22 \\
27\end{array}$ & 0.0000 \\
\hline \multicolumn{4}{|c|}{ Intermediate Phillips-Perron Test Results D (UNTITLED) } & \multicolumn{4}{|c|}{ Intermediate Phillips-Perron Test Results D (UNTITLED) } \\
\hline Series & Prob. & Bandwidth & Obs & Series & Prob. & Bandwidth & Obs \\
\hline LNGDP & 0.8803 & 5 & 80 & $\mathrm{D}$ (LNGDP) & $\begin{array}{c}0.001 \\
1\end{array}$ & 4 & 78 \\
\hline LNDEBTS & 0.8795 & 0 & 80 & D(LNLOANS) & $\begin{array}{c}0.000 \\
0\end{array}$ & 1 & 80 \\
\hline LNER & 0.1371 & 5 & 77 & D(LNER) & $\begin{array}{c}0.000 \\
0\end{array}$ & 2 & 79 \\
\hline LNBM & 0.2213 & 2 & 80 & $\mathrm{D}(\mathrm{LNBM})$ & $\begin{array}{c}0.000 \\
0\end{array}$ & 0 & 80 \\
\hline LNINF & 0.0054 & 1 & 75 & $\mathrm{D}(\mathrm{LNINF})$ & $\begin{array}{c}0.000 \\
0\end{array}$ & 0 & 80 \\
\hline LNPOP & 0.9408 & 12 & 80 & $\mathrm{D}(\mathrm{LNPOP})$ & $\begin{array}{c}0.000 \\
1\end{array}$ & 12 & 76 \\
\hline \multicolumn{4}{|c|}{$\begin{array}{c}\text { Notably: ** Shows the overall significance for the unit root } \\
\text { test at Source: STATA, } 2021\end{array}$} & \multicolumn{4}{|c|}{$\begin{array}{c}\text { Notably: ** Shows the overall significance for the unit root test at 5\%. } \\
\text { Source: STATA, } 2021\end{array}$} \\
\hline
\end{tabular}

Table 2: ADF test Results in levels and First Difference

\begin{tabular}{|c|c|c|c|c|c|c|c|c|c|}
\hline \multicolumn{3}{|c|}{ Method } & $\begin{array}{l}\text { Statist } \\
\text { ic }\end{array}$ & Prob.*** & \multicolumn{3}{|c|}{ Method } & $\begin{array}{l}\text { Statisti } \\
\text { c }\end{array}$ & Prob.** \\
\hline \multicolumn{3}{|c|}{ ADF - Fisher Chi-square } & $\begin{array}{c}26.333 \\
7\end{array}$ & 0.2376 & \multicolumn{3}{|c|}{ ADF - Fisher Chi-square } & 242.394 & 0.0000 \\
\hline \multicolumn{3}{|c|}{ ADF - Choi Z-stat } & $\begin{array}{c}1.2247 \\
2 \\
\end{array}$ & 0.8897 & \multicolumn{3}{|c|}{ ADF - Choi Z-stat } & $\begin{array}{c}- \\
12.7183 \\
\end{array}$ & 0.0000 \\
\hline \multicolumn{5}{|c|}{ Intermediate ADF test results UNTITLED } & \multicolumn{5}{|c|}{ Intermediate ADF test results D(UNTITLED) } \\
\hline Series & Prob. & $\begin{array}{l}\mathrm{L} \\
\mathrm{a} \\
\mathrm{g}\end{array}$ & $\begin{array}{l}\text { Max } \\
\text { Lag }\end{array}$ & Obs & Series & Prob. & $\begin{array}{l}\mathrm{L} \\
\mathrm{a} \\
\mathrm{g}\end{array}$ & $\begin{array}{l}\text { Max } \\
\text { Lag }\end{array}$ & Obs \\
\hline LNGDP & 0.9986 & 9 & 11 & 74 & $\mathrm{D}(\mathrm{LNGDP})$ & 0.0145 & 4 & 11 & 78 \\
\hline LNDEBTS & 0.8795 & 0 & 11 & 83 & D(LNLOANS) & 0.0000 & 0 & 11 & 82 \\
\hline LNER & 0.1409 & 0 & 11 & 83 & D(LNER) & 0.0000 & 0 & 11 & 82 \\
\hline LNBM & 0.2518 & 0 & 11 & 83 & $\mathrm{D}(\mathrm{LNBM})$ & 0.0000 & 0 & 11 & 82 \\
\hline LNINF & 0.0064 & 0 & 11 & 83 & D(LNINF) & 0.0000 & 7 & 11 & 75 \\
\hline LNPOP & 0.3674 & 8 & 11 & 75 & $\mathrm{D}(\mathrm{LNPOP})$ & 0.2475 & 7 & 11 & 75 \\
\hline \multicolumn{5}{|c|}{$\begin{array}{c}\text { Notably: ** Shows the overall significance for the unit root test at } \\
\text { 5\%. } \\
\text { Source: STATA, } 2021\end{array}$} & \multicolumn{5}{|c|}{$\begin{array}{l}\text { Notably: ** Shows the overall significance for the unit root test at } 5 \% . \\
\text { Source: STATA, } 2021\end{array}$} \\
\hline
\end{tabular}

All the variables as per the results attained from both the PP and ADF tests in Table 1 and 2 respectively do not become stationary at levels. Investigation based on non-stationary variables products imitation regression results. Consequently, calls for first differencing of the non-stationary variables. As a result, the first difference is used. From the PP class of test, every variable measured to clarify economic development became stationary at first difference at all the predictable levels. The case is special for the ADF test as population remains non stationary still after first difference. Particularly, this study will support on the results of the PP test to close that all variables become stationary at first difference. The PP test is favored over the ADF because the PP tests corrects for any serial correlation and heteroscedasticity in the errors non parametrically. The Phillips and Perron's test statistics can therefore be viewed as Dickey-Fuller statistics that have been made robust to serial correlation by using the Newey-West (1987) heteroscedasticity and autocorrelation consistent covariance matrix estimator. So, all the sequence is included of the same order i.e. I (1). This thus asserts that a Co integration test can be assumed to infer the continuation of a long run association.

B. Test for Co integration: Johansen Co integration test was used to examine whether there exists long-run association 
among the co integrating variables since all the variables are integrated of order one. The major aim of testing Co integration was to determine whether a linear combination of a group of non-stationary variables is stationary.

Table3: Co integration Results for the Long Run Associations (The Case of Economic Growth Including External Loans)

Unlimited Co integration Rank Test (Maximum Eigen Value)

\begin{tabular}{|c|c|c|c|c|}
\hline $\begin{array}{c}\text { Hypothesized } \\
\text { No. of CE(s) }\end{array}$ & Eigen value & $\begin{array}{c}\text { Max-Eigen } \\
\text { Statistic }\end{array}$ & $\mathbf{0 . 0 5}$ Critical Value & Prob.*** \\
\hline None* & 0.550342 & 64.74064 & 52.36261 & 0.0018 \\
\hline Atmost1 & 0.423317 & 44.58750 & 46.23142 & 0.0743 \\
\hline Atmost2 & 0.378689 & 38.54982 & 40.07757 & 0.0736 \\
\hline Atmost3 & 0.266303 & 25.08242 & 33.87687 & 0.3795 \\
\hline Atmost4 & 0.166240 & 14.72656 & 27.58434 & 0.7695 \\
\hline Atmost5 & 0.113739 & 9.780248 & 21.13162 & 0.7650 \\
\hline Atmost6 & 0.056957 & 4.750124 & 14.26460 & 0.7730 \\
\hline Atmost7 & 0.002970 & 0.240930 & 3.841466 & 0.6235 \\
\hline
\end{tabular}

Max-Eigen value Test Shows1 Co Integration (s) at the0.05Level; *Denotes Rejection of the Hypothesis at the0.05Level

**MacKinnon-Haug-Michelis (1999) P-Values

Source: STATA, 2021

Johansen cointegration test results show that there is one co integration equation at $10 \%$ level of significance in all luggage's. The null hypothesis of continuation of none cointegrating equation is rejected since the Max-Eigen statistic is greater than the $10 \%$ critical value in all luggage's. This additional implies that all the variables in the special models join to an equilibrium in the long run (i.e., are co integrated). This indicates that the variables used in the analysis are co integrated i.e., have a long run association and this required to run the Vector Error Correction Model (VECM) to additional decode the short- run dynamics.

The results of the long - run OLS regressions, deviation in Gross Domestic Product which is a substitute for economic development are well explicated by the regressors in the special models. This is conditional from the high R-Squared values for both. The results also show that a Prob (F- statistic) of 0.0000 for all models implying that the independent variables had good joint descriptive power on GDP. From the Table 3, all variables included in the different models are significant at the $5 \%$ level of significance with the observation earlier made $[4,7,9]$.

Crossways get on for all the models; the deviation is the level of significance for the different models. The regression with external loans depicts that it is significant at the $1 \%$ level while in the rest it is significant at 5\%. This implies that benefits other things constant, an increase in gross fixed capital formation by one percent leads to a $41 \%$ increase in GDP considering the case of a model with external loans. Efficient labor raise by one percent also increases economic development by $105 \%$ holding other things constant considering the case of a model with external loans. This finding for all the models is in quality with economic theory as inferred from the Solow growth model. Also, when capital is improved, in general it increases the productivity of labor and hence more productivity which breeds economic development. The exchange rate and inflation variables have rather vague signs from what was predictable in all the regressions i.e., they are positive. This implies that they play an imperative function in explaining economic development. This result may be true because in the short- run inflation may lead to economic expansion through instant profits by traders who plow these hence contributing to the general growth of income. Also, the government may understand an inflation tax which if well owed to productive ventures may spur development. Also, in observe to population, the results from all the regressions disclose that it's significant in explaining development significantly both at the 5 and $10 \%$ levels of significance.

Table4: OLS Long Run Regression Models

\begin{tabular}{|c|c|c|c|c|}
\hline GDP & LNLOANS & LNTECH & LNGRANTS & LNTA \\
\hline \multirow{2}{*}{ LNCAPITAL } & $0.413006^{* * *}$ & $0.24525^{* *}$ & $0.280018^{* *}$ & $0.251282^{* *}$ \\
& $(0.107919)$ & $(0.115116)$ & $(0.124902)$ & $1.0 .131117)$ \\
\hline \multirow{2}{*}{ LNEL } & $1.054242^{* * *}$ & $1.040248^{* * *}$ & $1.030377^{* * *}$ & $(0.160938)$ \\
& $(0.140691)$ & $(0.168995)$ & $(0.153569)$ & $0.33506^{* *}$ \\
& $0.254042^{* * *}$ & $0.336741^{* * *}$ & 0.342047 * $^{* * *}$ & $(0.110857)$ \\
\hline \multirow{2}{*}{ LNER } & $(0.095188)$ & $(0.101850)$ & $(0.102248)$ & $0.029128^{* *}$ \\
& $0.045406^{* * *}$ & $0.028358^{*}$ & $0.031589^{*}$ & $(0.015069)$ \\
\hline \multirow{2}{*}{ LNINF } & $(0.014384)$ & $(0.016125)$ & $(0.015875)$ & \\
\hline
\end{tabular}




\begin{tabular}{|c|c|c|c|c|}
\hline LNPOP & $\begin{array}{c}0.730101 * * \\
(0.306112)\end{array}$ & $\begin{array}{c}0.853099 * * \\
(0.336867)\end{array}$ & $\begin{array}{c}0.821731 * * \\
(0.341660)\end{array}$ & $\begin{array}{c}0.857536^{* *} * \\
(0.368635)\end{array}$ \\
\hline LNBM & $\begin{array}{c}-0.706196^{* * * *} \\
(0.207995)\end{array}$ & $\begin{array}{c}-0.989439^{* * * *} \\
(0.269864)\end{array}$ & $\begin{array}{c}-0.924631 * * * \\
(0.232963)\end{array}$ & $\begin{array}{c}-0.966866^{* * * *} \\
(0.230968)\end{array}$ \\
\hline LNLOANS & $\begin{array}{c}-0.113157^{* * * *} * \\
(0.029232) \\
\end{array}$ & & & \\
\hline LNTECH & & $\begin{array}{c}0.005191 * * * * \\
(4.227705)\end{array}$ & & \\
\hline LNGRANTS & & & $\begin{array}{l}-1.95 \mathrm{E}-11 \\
(4.03 \mathrm{E}-11)\end{array}$ & \\
\hline LNTA & & & & $\begin{array}{c}-0.000725 \\
(0.049190)\end{array}$ \\
\hline CONSTANT & $\begin{array}{c}-6.457145^{*} \\
(3.807363)\end{array}$ & $\begin{array}{l}-6.457145 \\
(0.131117)\end{array}$ & $\begin{array}{c}-6.052194 \\
(4.198776)\end{array}$ & $\begin{array}{c}-5.74411 \\
(4.289509)\end{array}$ \\
\hline $\begin{array}{c}\mathrm{R}^{\wedge} 2=0.993553 \\
\mathrm{~F}- \\
\text { statistic }=1673.112 \text { Pro } \\
\mathrm{b}(\mathrm{F}-\mathrm{stat})=0.0000\end{array}$ & $\begin{array}{c}\mathrm{R}^{\wedge} 2=0.994614 \\
\mathrm{~F}- \\
\text { statistic }=2005.132 \text { Pro } \\
\mathrm{b}(\mathrm{F}-\mathrm{stat})=0.0000\end{array}$ & $\begin{array}{c}\mathrm{R}^{\wedge} 2=0.993554 \\
\mathrm{~F}- \\
\text { statistic }=117.7720 \text { Pro } \\
\mathrm{b}(\mathrm{F}-\mathrm{stat})=0.0000\end{array}$ & $\begin{array}{c}\mathrm{R}^{\wedge} 2=0.993572 \\
\mathrm{~F}- \\
\text { statistic }=1678.276 \text { Pro } \\
\mathrm{b}(\mathrm{F}-\mathrm{stat})=0.0000\end{array}$ & $\begin{aligned} \mathrm{R}^{\wedge} 2 & =0.993553 \\
\text { F-statistic } & =1673.112 \operatorname{Prob}(\mathrm{F}- \\
\text { stat }) & =0.0000\end{aligned}$ \\
\hline
\end{tabular}

Standard errors in parenthesis

Note that*,**,*** Represent Level of Significance at the $10 \%, 5 \%$ and $1 \%$ Respectively

Source: STATA, 2021

Table 5: The Unit Root Test for the ECT of the Economic Growth Model with External loans

\begin{tabular}{|c|c|c|c|}
\hline \multicolumn{3}{|c|}{$\begin{array}{l}\text { Null Hypothesis: RESID01has a unit } \\
\text { root }\end{array}$} & \multirow[b]{4}{*}{ Prob.* } \\
\hline $\begin{array}{c}\text { Exogenou } \\
\text { s: } \\
\text { Constant } \\
\end{array}$ & & & \\
\hline \multicolumn{3}{|c|}{$\begin{array}{c}\text { Lag Length:8 (Automatic-based on SIC, } \\
\text { Max lag=11) }\end{array}$} & \\
\hline & & t-Statistic & \\
\hline \multicolumn{2}{|c|}{$\begin{array}{l}\text { Augmented Dickey- } \\
\text { Fuller test statistic }\end{array}$} & -2.957191 & 0.0437 \\
\hline \multirow[t]{3}{*}{$\begin{array}{c}\text { Test } \\
\text { critical } \\
\text { values: }\end{array}$} & $1 \%$ level & -3.520307 & \\
\hline & $5 \%$ level & -2.900670 & \\
\hline & $10 \%$ level & -2.587691 & \\
\hline \multicolumn{2}{|c|}{$\begin{array}{c}\text { *MacKinnon (1996) } \\
\text { One-Sided-Values. } \\
\text { Source: STATA, } 2021\end{array}$} & & \\
\hline
\end{tabular}

A lagged Error Correction Term (ECT) was fixed to the short run models as a descriptive variable to create the pace of change towards the equilibrium per period. The residual was taken as suitable ECT; therefore, the model resulted into the ECT. The coefficient of the remaining is interpreted as the speed of alteration or the amount of disequilibrium transmitted each period to Economic development. From the Error Correction Model regression with debts, the results show that the coefficient of the ECT (U (-1)) is -0.130069 which is less than one and significant at the $1 \%$ level. The significance of the ECT implies that when there is variation in economic development from a balance path, the model accurate at the rate of $13 \%$ quarterly. The negative coefficient of ECT and a P- Value of 0.0000 additional authenticate the fact that the regress and regressors have a long - run balance association with the observation earlier made $[2,5,10]$.
Although insignificant impact on expansion, external loans are still significantly detrimental to development even in the short- run given the sign of its coefficient. The model econometrically acts well as contingent from analytical tests in Figure 1.

The significance of the ECT implies that whenever there are deviations in economic development from a balance path, the model corrects at the rate of $0.08 \%$ quarterly. The negative coefficient of ECT and a P- Value of 0.0000 additional authenticates the fact that the regress and regressors have a long- run balance association with the observation earlier made $[9,11,16]$. Econometrically the model performs well. $63 \%$ of the deviation in economic development is explained by the variables captured in the short- run model. Inferring from the F- statistic the model can be rated as good at all conventional levels. The model does not infringe the classical assumptions as there is neither a problem of heteroscedasticity and serial correlation. Multicollinearity is also not a problem as inferred from the diagnostic Tests-Figure 2

Table6: OLS Error Correction Models

\begin{tabular}{|c|c|c|}
\hline GDP & LNDEBTS & LNTA \\
\hline D(LNEL) & $\begin{array}{c}0.374176^{* * * *} \\
(0.099274)\end{array}$ & $\begin{array}{c}0.282536^{* * * *} \\
(0.085922)\end{array}$ \\
\hline D(LNER) & $\begin{array}{c}0.142166^{* * *} \\
(0.069466)\end{array}$ & $\begin{array}{c}0.136820^{* *} \\
(0.067218)\end{array}$ \\
\hline D(LNINF) & $\begin{array}{c}0.009088 \\
(0.005626)\end{array}$ & $\begin{array}{c}0.007578 \\
(0.005424)\end{array}$ \\
\hline D(LNPOP) & $\begin{array}{c}-0.738578 * * \\
(0.354345)\end{array}$ & $\begin{array}{l}-0.466233 \\
(0.327750)\end{array}$ \\
\hline $\mathrm{D}(\mathrm{LNBM})$ & $\begin{array}{c}-0.602630 * * * \\
(0.081003)\end{array}$ & $\begin{array}{c}-0.633796 * * * \\
(0.079755)\end{array}$ \\
\hline ECT & $\begin{array}{c}-0.130069 * * * \\
(0.038368)\end{array}$ & $\begin{array}{c}-0.131282 * * * \\
(0.033386)\end{array}$ \\
\hline D(DEBTS) & $\begin{array}{c}-0.036497 * * \\
(0.016421)\end{array}$ & \\
\hline \multirow[t]{2}{*}{ D(LNTA) } & & $\begin{array}{c}0.025555 \\
(0.018027) \\
\end{array}$ \\
\hline & $0.030624 * * *$ & $0.030645^{* * *}$ \\
\hline
\end{tabular}




\begin{tabular}{|c|c|c|}
\hline CONSTANT & $(0.002095)$ & $(0.002017)$ \\
\hline & $\mathrm{R}^{\wedge} 2=0.994614$ & $\mathrm{R}^{\wedge} 2=0.660858$ \\
$\mathrm{R}^{\wedge} 2=0.640435$ & $\mathrm{~F}-$ & $\mathrm{F}-$ \\
F-statistic $=16.47550 \operatorname{Prob}(\mathrm{F}-$ & statistic=2005.1 & statistic=18.02470 \\
stat) $=0.0000$ & $\begin{array}{c}\text { P2Prob(F-stat) } \\
=0.0000\end{array}$ & $\begin{array}{c}\text { Prob(F-stat) } \\
=0.0000\end{array}$ \\
\hline
\end{tabular}

Standard Errors in Parenthesis; Note that*, **, ***Represent Level of Significanceatthe $10 \%, 5 \%$ and $1 \%$ respectively

Source: STATA, 2021

Believing the case of external debts, $65 \%$ of deviations in GDP are explained by the regressors in the model. The negative coefficient of ECM is significant thus explanatory the continuation of a co integrating association between the variables. It implies that when an exogenous upset interrupt the balance circumstance, $14 \%$ of its effect is adjusted within one period/quarter.

Unlike in the long run where grants had a positive but insignificant impact on growth, the reverse is the case for the short run. The effects of external debts caries a similar directional effect of economic within the short- run jointly with external debts although for it, its effects is insignificant with the observation earlier made [2, 8, 13, 21, 22, 23, 24].

C. Normality Test: To make valid inferences from your regression, the residuals of the regression should follow a normal distribution. The residuals are simply the error terms or the differences between the observed value of the dependent variable and the predicted value see Figure 1.

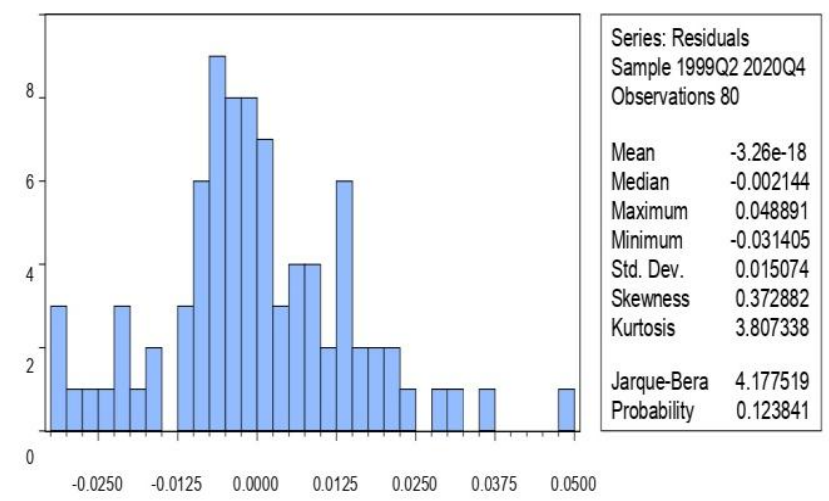

Figure 1: Normality Test Results

Source, STATA, 2021

Finally, from the short- run model depicting total external debts, the results raveled that the coefficient of the ECT (U ($1)$ ) is - -0.131282 which is less than one and significant at the $1 \%$ level. The significance of the ECT implies that whenever there are variations in economic development from a balance path, the model corrects at the rate of $13 \%$ quarterly. The negative coefficient of ECT and a P- Value of 0.0000 additional authenticate the fact that the regress and regressors have a long-run balance association. Econometrically the model performs well. $66 \%$ of the deviation in economic development is explained by the variables arrested in the short-run model. The descriptive power of external debts is higher than the case when we consider one form of disaggregated aid alone although the difference is only about $1 \%$. Inferring from the $\mathrm{F}$ statistic the model can be rated as good at all conventional levels. The model does not violate the classical assumptions as there is neither a problem of heteroscedasticity and serial correlation. Notably all the results obtained from the CUSUM stability tests as in the Figure 2 on the different growth error correction models depicted stability. This implies that it's probable to accurately predict economic development in Kenya. Parameter faithfulness is also not in hesitation for all the different ECM with the observation earlier made [4, 9, 16, 19 20].

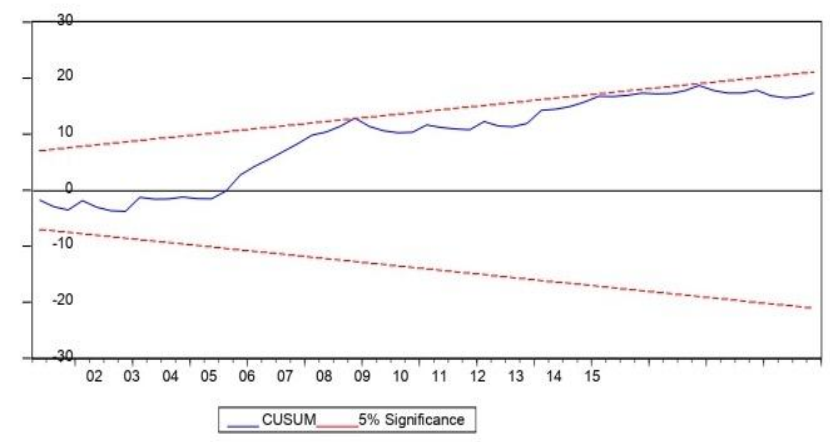

Figure 2: Model Stability of the Study

Source: STATA, 2021

Table 7: Heteroskedasticity Test: Breusch-Pagan-Godfrey

\begin{tabular}{|c|c|c|c|}
\hline F-statistic & 0.572486 & Prob.F(8,74) & 0.7972 \\
\hline Obs*R-squared & 4.837505 & $\begin{array}{c}\text { Prob.Chi- } \\
\text { Square (8) }\end{array}$ & 0.7748 \\
\hline Scale explained SS & 5.397508 & $\begin{array}{c}\text { Prob.Chi- } \\
\text { Square (8) }\end{array}$ & 0.7144 \\
\hline \multicolumn{4}{|c|}{ Breusch-Godfrey Serial Correlation M Test: } \\
\hline F-statistic & 26.70772 & Prob.F(2,70) & 0.0530 \\
\hline Obs*R-squared & 35.05761 & $\begin{array}{c}\text { Prob.Chi- } \\
\text { Square (2) }\end{array}$ & 0.0710 \\
\hline
\end{tabular}

Source: STATA, 2021

Figure 3 shows the relationship between external debts and sustainable economic development from 1999/20-2019/20 in Kenya. In general, the debt of the government of the United Republic of Kenya is still sustainable. evidenced recent evidence was produced by the Minister of Finance, in the budget speech of 2018/2019, "The ratio of government debt to GDP is $34.4 \%$ compared to the $56 \%$ limit; The value of the External Debt only for GDP is $19.17 \%$ compared to the limit of $40 \%$," Budget speech $(2018 / 2019$. In translation, the government debt to GDP ratio is $34.4 \%$ compared to the limit of $54 \%$, external public debt to the GDP ratio is $19.17 \%$ compared to the limit of $40 \%$ with the observation earlier made $[5,8,15]$. 
Also, the multiple regression model of the study revealed that there is long - term associations between external debts and sustainable economic development with P- Value of 0.0001 in United Republic of Kenya. Also, explained significantly by all the other macro-economic variables in the predictable direction with P- Value of 0.0011 United Republic of Kenya, except broad inflation and money that have vague signs. In short-run revealed that external debts affect statistically significance economic development with a negative direction P- Value of 0.0064 in United Republic of Kenya. As per Figure 3 shows the modal stability between external debt and economic development.
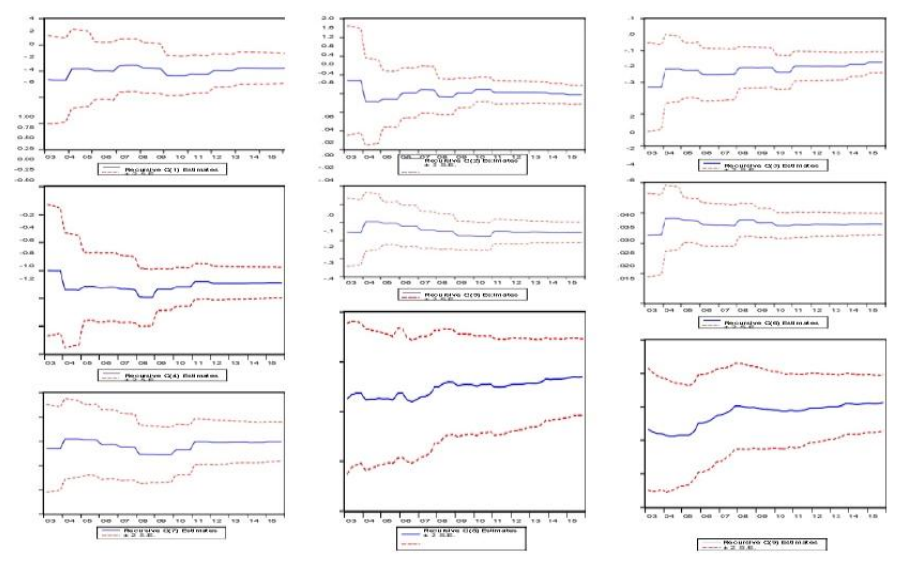

Figure 3: Overall Model Stability of the Study

Source: STATA,2021

The study observed that there is long -term associations between external debts and sustainable economic development with the observation earlier made $[3,7,18]$. Also, explained significantly by all the other macro-economic variables in the predictable direction except broad inflation and money that have vague signs. In short-run observed that external debts affect statistically significance economic development with the observation earlier made $[9,1,17]$ who found a significant correlation in a long run and short run between external debt and economic growth. The study recommends that the government should think adopting other sources of finance articulate via taxation and reduce borrowing outside to eradicate assistance from developed countries. The government should also assign extra resources to savings in human capital education as efficiently labor has the effect of promoting economic development crosswise all models in the short run. Particularly population expansion rate should be proscribed through increasing utilize of social services such as family planning or sensitization to eradicate support pressure on imperfect resources which deject economic development.

The researcher suggests that the future researchers particularly to focus a panel data analysis of the East African Countries (EAC) may be taken to permit for a comparative breakdown of the performance of Kenya with other East Africa Community regions.

\section{REFERENCES}

[1] Dalton, P. S., Ghosal, S., \& Mani, A., "Poverty and Aspirations Failure," The Economic Journal, vol. 26, no. 590, pp. 165-188, 2016.

[2] Darma, N. A., "The Impact of Nigeria's Debt Stock and its Servicing on Social ServicesProvision:1980-2010," Journal Developing Country Studies, vol.4, no.10, pp. 187-19, 2014.

[3] Girma, P. H., "The Impact of Foreign Aid on Economic Growth: Empirical Evidence from Ethiopia (1974-2011) Using ARDL Approach, "Journal of Research in Economics and International Finance (JREIF), vol. 4, no. 1, pp. 1-12, 2015.

[4] Irungu, J., "Household food security in semi-arid Africa, the contribution of participatory adaptive research and development to rural livelihoods in Eastern Kenya," Journal of Food Policy, vol. 24, no.4, pp. 363-390, 2016.

[5] Kanbur, R., "The Economics of International Aid," Handbook of the Economics of Giving, Altruism and Reciprocity, vol. 2, no. 1, pp. 1559-1588, 2016.

[6] Lin, J. Y., "New Structural Economics: A Framework for Rethinking Development 1," The World Bank Research Observer working Paper, vol. 26, no. 2, pp. 193-221, 2011.

[7] Matelis, A., \& Huettinger, M., "Effects of external financial debt on various economic sectors in Latin America, "Master's Thesis, ISM University of Management and Economics, pp. 5-39, 2014.

[8] Najeb, M., "A Contribution to the Theory of Economic Growth: Old and New." Journal of Economics and International Finance, vol. 6 , no. 3, pp. 20- 47, 2014.

[9] Nwanne, T. F. I., \& Richard, E. O., Assessing the Effect of External Debt Servicing andReceipt on Exchange Rate in Nigeria., "International Journal of Economics and Finance, vol.7, no. 9, pp. 225- 278, 2015.

[10] Okonkwo, C. S., \&Odularu, G. O., External Debt, Debt Burden and Economic Growth Nexus: Empirical Evidence and Policy Lessons from Selected West African Countries," International Journal of Economics \&Business Studies, vol. 3, no. 1, pp. 23-86, 2013.

[11] Refaei, R., \& Sameti, M., "Official Development Assistance and Economic Growth inIran, International Journal of Management, Accounting and Economics, vol. 2, no.1, pp. 125-13, 2015.

[12] Seiber,M.J.,

"InternationalBorrowingbyDevelopingCountries:PergamumPolicy Studieson International Development. Elsevier Publisher, vol 2, no.1 pp. 2-9, 2013.

[13] Sulaiman ,L.A.,\&Azeez, B.A., "Effect of External Debt on Economic Growth of Nigeria," Journal of Economics and Sustainable Development, vol. 3, no. 8, pp.71-79, 2012.

[14] Tasew, P. H., "The Impact of Foreign Aid on Economic Gowth: Empirical Evidence from Kenya (1974-2011) usingARDLapproach.JournalofResearchinEconomicsandInternatio nalFinance(JREIF), vol. 4, no. 1, pp. 1-12, 2015.

[15] Tavakol, M., \& Dennick, R., "Making Sense of Cronbach's Alpha, "International Journal of Medical Education, vol. 2, no. 1, pp. 53$55,2011$.

[16] Uma, K., Eboh, F., \& Obidike, P., "Debt and Debt Service: Implications on Nigerian Economic Growth," Asian Journal of Social Sciences and Humanities, vol. 2, no. 2, pp. 42-54, 2013.

[17] Yusuf, S and Said, O.A., "Public Debt and Economic Growth: Evidence from Tanzania," Journal of Economics, Management and Trade, vol. 21, no. 7, pp. 1-1, 2018

[18] Tyagi Ruchi., Vishwakarma S., Alexandrovich Z.S., Mohammed S. (2020). ICT Skills for Sustainable Development Goal 4. In: Leal Filho W., Azul A.M., Brandli L., Özuyar P.G., Wall T. (eds) Quality Education. Encyclopedia of the UN Sustainable Development Goals. Springer, Cham. DOI https://doi.org/10.1007/978-3-319-95870-5_39

[19] Tyagi R., Vishwakarma S., Yadav S.S., Stanislavovich T.A. (2021) Community Self-Help Projects. In: Leal Filho W., Azul A.M., Brandli L., Lange Salvia A., Özuyar P.G., Wall T. (eds) No 
Poverty. Encyclopedia of the UN Sustainable Development Goals. Springer, Cham. https://doi.org/10.1007/978-3-319-95714-2_28

[20] Tyagi R., Vishwakarma S., Singh K.K., Syan C. (2020) Low-Cost Energy Conservation Measures and Behavioral Change for Sustainable Energy Goal. In: Leal Filho W., Azul A.M., Brandli L., Lange Salvia A., Wall T. (eds) Affordable and Clean Energy. Encyclopedia of the UN Sustainable Development Goals. Springer, Cham. https://doi.org/10.1007/978-3-319-71057-0_1551

[21] Tyagi R., Vishwakarma S., Rishi M., Rajiah S. (2021) Reducing Inequalities Through Education and Skill Development Courses. In: Leal Filho W., Azul A.M., Brandli L., Lange Salvia A., Özuyar P.G., Wall T. (eds) Reduced Inequalities. Encyclopedia of the UN Sustainable Development Goals. Springer, Cham. https://doi.org/10.1007/978-3-319-71060-0_102-1

[22] Tyagi, Ruchi K and Vasiljevien, Nijole (2013) The case of CSR and irresponsible management practices. Competitiveness Review.
23(4/5):372-383. https://doi.org/10.1108/CR-03-2013-0031 .

Available online

at

https://www.emerald.com/insight/content/doi/10.1108/CR-03-

2013-0031/full/html

[23] Tyagi R. (2012) Meerut Embroidery Cluster: A Case Study. South Asian Journal of Business and Management Cases. 1 (2): 185-202. SAGE Publications Sage India: New Delhi, India. Available online at https://doi.org/10.1177/2277977912459445

[24] Vishwakarma, S. and Tyagi, R. (2017), "post-reforms training needs of frontline managers in Indian power distribution companies: A top managers' perspective", International Journal of Energy Sector Management. 11(3): 416425.https://doi.org/10.1108/IJESM-02-2016-0001. Accessed at https://www.emerald.com/insight/content/doi/10.1108/IJESM-022016-0001/full/html 